INTERNATIONAL JOURNAL OF RESEARCHES IN BIOSCIENCES, AGRICULTURE AND TECHNOLOGY C VISHWASHANTI MULTIPURPOSE SOCIETY (Global Peace Multipurpose Society) R. No. MH-659/13(N) www.ijrbat.in

\title{
EFFECT OF AIR POLLUTANTS ON PROTEIN AND GLUCOSE LEVEL OF ALBINO RAT AT INDORE (M.P.)
}

\author{
Ruchi Tiwari and Meena Khare \\ Department of zoology, Mata Jija Bai Govt. Girls PG College, Indore \\ ruchitiwari_24@yahoo.com
}

\begin{abstract}
:
The aim of the present study is to evaluate the impact of Air pollutants $\left(\mathrm{PM}_{10}, \mathrm{SO}_{2}\right.$ and $\mathrm{NOx}$ ) on some biochemical parameters of Albino rat. Three different sites of Indore city viz; Kothari market (commercial), Sanver road (industrial) and Vijay nagar (residential) were selected for investigation. Animal was exposed for four months (June to September) on these sites and Blood samples were collected for estimation of Protein (g/dl) and Glucose $(\mathrm{mg} / \mathrm{dl})$ level. Results indicate the decreased level of Protein and Glucose $(\mathrm{P}<.01 \%)$. Pollutants level of these sites was more than tolerable limit. The values of experimental group were significant checked by student T-test. The study reveals that Air pollutants adversely affect on biochemistry of Albino rat.

Keywords: Air pollutants, Indore, Albino rat, Protein, Glucose.
\end{abstract}

\section{Introduction}

Indore growing rapidly in size and diversity with increasing emission from vehicle, industries, and traffic. Millions of peoples are exposed to this poor quality air. This air badly effect the lung eye nose and whole respiratory tract, causes serious health problem like Asthama, Bronchitis, Emphysema, Elergy. According to figure available with Madhya Pradesh pollution control board in Indore emission from vehicle cause the maximum pollution in the city .Around $60 \%$ of the entire particulate matter is caused due to vehicular emission while the rest caused by industrial and domestic pollution (Hindustan times June 5,2016 , Nida Khan).Air pollution is one of the major causative factor behind the 10-12\% incidence of bronchial asthma in the age group of 5-6 year in India (Chabra 1996).In Indore city the standard level of pm 10 must be $60 \mathrm{mg}$ $/ \mathrm{m} 3$ but now a days it reaches up to $200 \mathrm{mg} / \mathrm{m} 3$ and more the condition are worst in the month of summer because dust particles are as more as compare to other month .They are easily inhaled and entered in the lung. Asthmatic population appears to be more susceptible to the impact of particulate and SO2 exposure (Mukhopadhyay 1997).

Particulate matter alone or in combination with $\mathrm{SO} 2$ are found to be major cause of illness of health that leads to at least 500,000 premature death and 4-5 million new cases of chronic bronchitis every year (World Bank Report, 1992).

In Indore city the standard level of PM 10 must be $60 \mathrm{mg} / \mathrm{M} 3$ but now days it reaches up to $200 \mathrm{mg} / \mathrm{M} 3$ and more. The conditions are worst in the month of summer because dust particles are as more as compare to other months. They are easily inhaled and entered in the lungs tissue. It consisting of complex and varying mixture of particles suspended in the breathing air, which vary in size and composition, and are produced by a wide variety of natural and anthropogenic activities (Poschl, 2005).

Thus looking to the importance regarding good health of the citizens of Indore city, the present investigation has been aimed to assess the Biochemical parameters in albino rat on exposure to air pollution in Indore city.

\section{Materials and Methods Experimental Animal}

Albino rat (male and female) were purchased from registered shop and kept in cages. Each cage contains 6 rats, out of which 5 were female and 1 male. Weight of animal was measured as 150-200 grams. Animal will be active and disease free. Food and water will be provided in sufficient amount to animal.

\section{Experimental Area}

Indore-Indore City located at 220 43' latitude (North) and 750 57'Longitude (East) with general elevation of about 550 meters above mean sea level (MSL). It is located on the southern edge of Malwa plateau. The city is located $190 \mathrm{~km}$ west of the state capital of Bhopal. Average humidity is reported as $50 \%$ (Source HKO).

Experimental Design- Animals were divided into two groups.

Control Group - In this group, 6 rats were taken in cage ( 5 male rats and 1 female rat). Here sufficient amount of animal food and water will be given to animal under controlled conditions.

Experimental Group - In this group, three cages will be prepared. Each cage contains 6 rats (ratio will be same as control group), than animal will be exposed to the selected sites viz: 
Vijay Nagar (residential), Kothari Market (commercial) and Sanver Road (industrial).

Exposure Duration-One year exposures were given to animal. Data of June-July and August-September (2014-15) were documented and analysed statically.

Biochemical study- Blood sample were collected from the retro orbital puncture. The collected blood sample were centrifuged a $3000 \mathrm{rpm}$ for 10 minutes to separate the sera. The sera were kept in deep freezer for further analysis of different parameters.

Statistical analysis - The results of present investigation were expressed as mean (Triplicate) and standard deviation. The level of significance between the means of control and the experimental groups were analyzed by Student's t-test. Whereas, their differences were found to be statistically significant at $\mathrm{P}<.01$ except $\left(^{*}\right)$ which are significant at $\mathrm{P}<0.05$.

Results The control value of protein (g/dl) were reported as $7.21 \pm 0.0100$ where as in Kothari market, Sanver road and Vijay nagar the values were reported $2.47 \pm 0.0346$, $1.44 \pm 0.0153$ and $2.67 \pm 0.0267$. The control value of glucose $(\mathrm{mg} / \mathrm{dl})$ during June-July $58.21+0.1102$, and experimental values were $48.31 \pm 0.0656 \quad 43.31+0.0557 \quad$ and $52.00 \pm 0.5292$ estimated in Kothari market, Sanver road and Vijay nagar respectively (Table-1).

Similarly these values were recorded in the month of August -September .The value of protein was $17.81 \pm 0.0173$ in control group where as in experimental group in three different experimental zones were 2.0 \pm 0.0404 , $1.21 \pm 0.0153$ and $2.67 \pm 0.0265$ respectively. The control value of glucose were reported $80.00+ \pm 0.1007$ where as in Kothari market Sanver road and Vijay nagar the values were $58.17 \pm 0.0289, \quad 57.21 \pm 0.0458$ and $40.00 \pm 0.0404$ respectively (Table-2).

\section{Discussion}

In present investigation the protein $(\mathrm{g} / \mathrm{dl})$ and glucose level was found to be decreased $(\mathrm{P}<.01)$ except $\left({ }^{*}\right)$ which are significant at $(\mathrm{P}<0.5)$ at Indore city in all three mentioned sites. Protein is very essential biomolecule for body development and different mechanical functions like cell signalling, immune response, cell adhesion and cell cycle. Further studies found that these all protein dependent cycles were effected due to protein alteration as, study on exposures to high particulate air pollution found alveolar inflammation that release mediators capable of exacerbating lung disease and increased blood coagulability in eosinophils individuals (Seaton, 1995). Several studies found abnormal red cell, neutrophil and platelet levels (Salvi et al., 1999), increase in blood viscosity (Schwartz, 2001), and changes in the number of T-lymphocytes, Blymphocytes, and NK cells (Salvi et al., 1999) in response to air pollution exposure. PM10 associated with alteration in glucose HbAlc and lipid, especially among people with diabetes (Maayan YS, 2016).

\section{References}

Chhabra, S.K. Prevalence of Bronchial Asthma in school children of Delhi Vallabbhai Patel Chest Institute New Delhi. (1996).

Maayan Yitshak Sade, Itai Kloog, Idit F. Liberty, Joel Schwartz, and Victor Novack "The Association between Air Pollution Exposure and Glucose and Lipids Levels". J Clin Endocrinol Metab, 101(6):2460-2467. (2016).

Mukhopadhyay K. "Industrial $\mathrm{CO} 2$ emission in India during 1991-92 to 1996-97". An inputoutput approach paper. Accepted for the 36th Annual conference on the India econometric society held at Devi Ahilya University, Indore (4-6 Feb'). (2003).

Poschl, U. "Atmospheric aerosols: composition, transformation, climate and health effects". Angew. Chem. Int. Ed. Engl. 44, 7520. (2005).

Salvi S, Blomberg A, Rudell B, Kelly F, Sandstrom T, Holgate ST, Frew A. Acute inflammatory responses in the airways and peripheral blood after short-term exposure to diesel exposure in healthy human volunteers. Am J Respir Crit Care Med, 159, 702-709, 1999.

Schwartz J, Ballester F, Saez M, Perez-Hoyos S, Bellido J, Cambra K, Arribas F, Canada A, Perez-Boillos MJ, Sunyer J. The concentrationresponse relation between air pollution and daily deaths. Environ Health Perspect, 109,1001-1006, 2001.

Seaton A, MacNee W, Donaldson K, Godden D. Particulate air pollution and acute health effects. Lancet, 345, 176-178, 1995.

World Bank Report). World Bank publication. (1992). 